\title{
Considering the Capital Account
}

\author{
Michael R. Pakko
}

$\mathrm{T}$

he U.S. balance of payments summarizes all economic transactions between the United States and the rest of the world. Within the balance of payments are a number of accounts, the most commonly cited being the trade account, which measures imports and exports of goods and services. A broader measure, known as the current account, also includes income payments (including returns on assets, such as interest and dividends) and net unilateral transfers. On the other side of the ledger, however, is an account known officially as the "capital and financial account." Often referred to simply as the capital account, this measure of the U.S. external balance records changes in the ownership of assets between U.S. and foreign entities.

As a matter of bookkeeping principle, the current account and capital account are two sides of the same coin: A country that is running a current account deficit-importing more goods and services than it is exporting-is necessarily also running a capital account surplus, exporting more assets than it is importing. Indeed, with the exception of a statistical discrepancy that reflects errors and omissions in the data, the current account and capital account sum to zero. It is sometimes implied that the capital account responds passively to the current account-for instance, that the U.S. capital account surplus is "financing" the U.S. trade deficit. But it is surely more complicated than that.

As worldwide trade and commerce have become increasingly integrated, cross-border flows of assets have grown remarkably. For example, foreign-owned assets in the United States increased from less than $\$ 2.5$ trillion in 1990 to over $\$ 10$ trillion by the end of 2003. Over the same period, U.S.-owned assets abroad increased from $\$ 2.3$ trillion to nearly $\$ 7.9$ trillion.

As these figures suggest, the U.S. net international investment position has been negative for several years now (since the mid1980s, in fact). Nevertheless, U.S. net income on investments has remained positive-which indicates that on average, U.S. investments abroad have generated higher returns than have foreign investments in the United States. The chart illustrates this pattern by showing annual figures for investment income as a percentage of assets for U.S. investments abroad and foreign investments in the United States. These measures indicate a persistent gap in the income generated from cross-country asset holdings.

Why does this gap in total returns exist? In recent remarks before a trade forum, Federal Reserve Bank of St. Louis President William Poole suggested the analogy of a financial intermediary:
"For some purposes, it is useful to think of U.S. financial markets as serving as a world financial intermediary. Just as a bank, or a mutual fund, channels the savings of many individuals toward productive investments, the U.S. financial markets play a similar role for many investors from around the world...A bank earns a return on its capital by holding assets that have a higher yield than the interest rate it pays to depositors. Similarly, the United States earns a higher return on its investments abroad than foreigners do on their investments in the United States." ${ }^{1}$

Given the unparalleled efficiency, transparency, and liquidity of U.S. financial markets, investors find that dollar-denominated claims are an attractive element of any international portfolio. This process of investors seeking the most beneficial combination of risk and return, rebalancing portfolios when opportunities arise, gives rise to a source of capital account dynamics that is unrelated in any direct way to the pattern of trade in goods and services. So, although they are closely related in an accounting sense, a full understanding of the U.S. balance of payments position is incomplete without considering both the current account and the capital account.

\footnotetext{
${ }^{1}$ Remarks before the Growing Global program of the World Trade Center Saint Louis. The text of this and other speeches delivered by President Poole can be found at http://stlouisfed.org/news/speeches.
}

\section{Investment Income as a Percent of Asset Holdings}

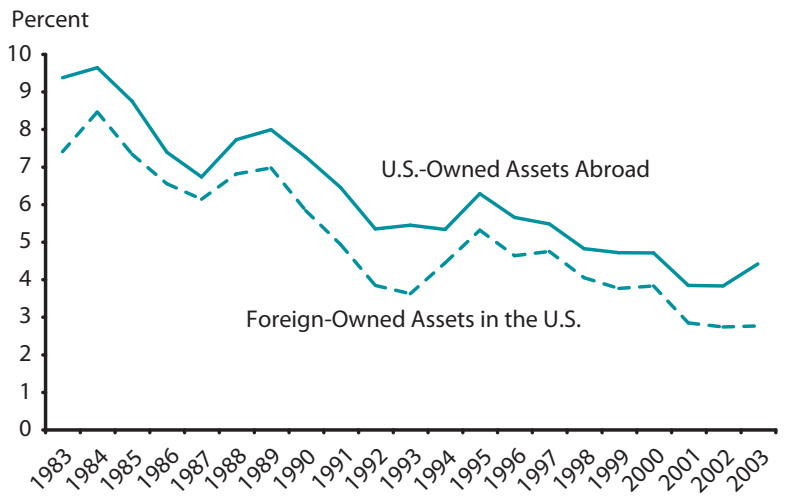

NOTE: Each series shows the ratio of income on investments (from the balance of payments accounts) to total asset holdings at the end of the previous year (from the international investment position of the U.S.).

SOURCE: BEA and the author's calculations. 